\title{
Understanding the Use of Social Media to Foster Student Creativity: A Systematic Literature Review
}

\author{
Daniela Rezende Vilarinho-Pereira1, Adrie A. Koehler2, \\ and Denise de Souza Fleith 3 \\ 1 Curriculum and Instruction, Purdue University, USA, Institute of Psychology, University of Brasilia, Brazil \\ 2 Curriculum and Instruction, Purdue University, USA \\ 3 Institute of Psychology, University of Brasilia, Brazil
}

\begin{abstract}
Social media have been increasingly used by youth to communicate with peers, access information, share creations, and express themselves. As a result, educators and researchers have recognized the potential for using social media to enhance teaching and learning experiences. Some scholars have also identified a relationship between social media integration and promoting student creativity. However, as with any educational technology, using a tool, such as social media, does not automatically increase creativity. In other words, the specific methods used to integrate social media as part of a learning experience affect the tool's influence on the learning process. Therefore, the purpose of this study was to review literature considering the use of social media in formal learning environments and examine their relationship with enhancing student creativity. We conducted a search to locate empirical studies (qualitative, quantitative, or mixed method) published between 2010 and 2020 from the Academic Search Premier, Education Full Text, Education Source, ERIC, and PsychINFO databases. In the results, we describe how social media were used for instructional purposes in the selected studies and discuss the social media affordances that lead to
\end{abstract}

\section{Article history:}

Corresponding author at:

Received: May 7, 2021

Received in revised from: June 29, 2021

Daniela Rezende Vilarinho-Pereira

Accepted: June 30, 2021

E-MAIL: dvilarin@purdue.edu

ISSN 2354-0036

DOI: 10.2478/ctra-2021-0009 


\section{INTRODUCTION}

Increasingly, social media are used by youth to communicate with peers, access information, share creations, and express themselves (Valiente-Neighbours, 2020). Bruns (2008) coined the term "produser" to describe how social media users are both producers and consumers (i.e., users) of information. As social media offer users opportunities to explore these dual roles, educators and researchers have recognized the potential for using social media to enhance teaching and learning experiences (Kimmons, 2014; Risser, Bottoms, \& Clark, 2019).

Specifically, as social media are commonly accessed through mobile devices that can extend traditional learning experiences beyond classroom boundaries, educators can design learning opportunities that connect informal and formal elements by coordinating collaborative efforts between learners with others and with targeted information (Cochrane \& Narayan, 2017). Due to these possibilities, some educators and scholars have identified a relationship between the integration of social media for teaching and learning purposes and the potential for prompting students' creativity. That is, research suggests that social media offer increased chances for learners to interact with others leading to increased creativity (Rasheed et al., 2020), and when paired with mobile technology, social media can facilitate feedback among teachers and peers prompting a reconsideration of traditional teacher and student roles and learning environments (Cochrane \& Narayan, 2017). In short, when enhancing student-centered approaches using social media, educators have new methods for creating environments to develop learning communities, which in turn prompts student creativity (Cochrane \& Narayan, 2017).

However, as with any educational technology, using a tool, such as social media, does not automatically increase creativity. In other words, the specific methods used to integrate social media as part of a learning experience affect the tool's influence on the learning process (OECD, 2015). As a result, to successfully boost student creativity through the use of social media for instructional purposes, educators must be intentional with how they are selecting, designing, and implementing learning experiences using social media. In this research, we consider previous research that investigated the use of social media in formal educational environments and examined their relationship with enhancing student creativity. Through this examination, we offer suggestions to successfully use the affordances emerging from the intersection of social media and creativity.

\section{SOCIAL MEDIA}

Social media have become a crucial part of daily lives and contemporary culture (boyd, 2014). Although a multitude of social media platforms and applications are available, a universally accepted definition of social media does not exist (Zhao, Liu, Tang, \& Zhu, 2013). McCay-Peet and QuanHaase (2016) defined social media as "web-based services that allow individuals, communities, and 
organizations to collaborate, connect, interact, and build community by enabling them to create, co-create, modifies, share, and engage with user-generated content that is easily accessible" (p. 6).

Researchers have categorized social media in a variety of ways (e.g., Boulos \& Wheeler, 2007; Bower, 2016; Koehler \& Ertmer, 2016; Mao, 2014; McCay-Peet \& Quan-Haase, 2016; Orehovački, Bubaš, \& Kovačić, 2012; Scott, Sorokti, \& Merrell, 2016). Categories include social networking sites (e.g., Facebook and Linkedln), blogs (e.g., WordPress and Blogger), wikis (e.g., PBworks and Notion), microblogging (e.g., Twiter and Tumblr), collaborative authoring or editing (e.g., Google Docs), instant messaging (e.g., WhatsApp and Telegram), idea mapping (e.g., Miro and Mindomo), social bookmarking (e.g., Pinterest and StumbleUpon), podcasting (e.g., Apple Podcasts), social news (e.g., Reddit), and media sharing (e.g., YouTube and Vine). With several diverse social media platforms, educators have numerous opportunities to facilitate communication and collaboration, and with the widespread access to social media and popularity, these tools have great potential to support educational programs for all ages.

\section{SOCIAL MEDIA ENHANCED TEACHING AND LEARNING}

Educators and researchers have recognized the potential for using social media to enhance teaching and learning experiences (Kimmons, 2014; Risser et al., 2019). By using social media platforms, students and teachers gain access to and participate in global digital communities, which provide opportunities for extending learning beyond the boundaries of a classroom. The possibility of students creating their own personal learning environment (PLE) can enrich learning and create a student-centered approach (Lim \& Newby, 2020). According to the authors, when allowing students to select social media that best help them achieve their goals and meet their interests, teachers must equip and support students to make these decisions.

Research considering how social media enhance teaching and learning experiences has focused on writing skills (e.g., Lee \& Kim, 2016); language acquisition (e.g., Altanopoulou, Tselios, Katsanos, Georgoutsou, \& Panagiotaki, 2015); technology literacy (e.g., Gachago, Livingston, \& Ivala, 2016); collaborative learning (e.g., Sun, Lin, Wu, Zhou, \& Luo, 2018); learning within a community (e.g., Lee \& Bonk, 2016); problem-based learning (e.g., Lau, Lui, \& Chu, 2017); and self-regulation (e.g., Yeo \& Lee, 2014), among other areas of learning.

One reason for the usefulness of social media in daily life and in education is their affordances. Affordances are the "relations between the abilities of organisms and features of the environment" (Chemero, 2003, p. 189). In this sense, when an object or environment (e.g., social media) is analyzed by its affordances, it is not its properties or features alone that are being described, but rather the qualities from the interactions between agent and object or environment (Chemero, 2003; Gaver, 1991; Greeno, 1994). This perspective allows teachers and students to focus on the utility of digital technology tools (e.g., social media), which facilitates connections between their use and instructional goals (Koehler \& Vilarinho-Pereira, 2020). 
Several authors from different fields (e.g., education, sociology, and communication) have presented multiple social media affordances. Association (Koehler \& Vilarinho-Pereira, 2020; Treem \& Leonardi, 2013), awareness (Rice et al., 2017), editability (Rice et al., 2017; Treem \& Leonardi, 2013), identity creation (Koehler \& Vilarinho-Pereira, 2020), ownership (Koehler \& Ertmer, 2016; Koehler, Newby \& Ertmer, 2017), persistence (boyd, 2014; Koehler \& Vilarinho-Pereira, 2020; Treem \& Leonardi, 2013), pervasiveness (Rice et al., 2017), searchability (boyd, 2014; Koehler \& Vilarinho-Pereira, 2020; Rice et al., 2017), self-presentation (Rice et al., 2017), spreadability (boyd, 2014), and visibility (boyd, 2014; Koehler \& Vilarinho-Pereira, 2020; Rice et al., 2017; Treem \& Leonardi, 2013) are prominent social media affordances presented and studied in the literature (See Table 1 for a brief description of each affordance referenced).

\section{Table 1. Affordances and Their Descriptions}

\begin{tabular}{|c|c|}
\hline Affordance & Description \\
\hline Association & $\begin{array}{l}\text { Association offers learners the possibility to use social media to connect or associate with other } \\
\text { individuals (e.g., peers, instructors, and experts in an area) and with information (Koehler et al., 2017; } \\
\text { Koehler \& Vilarinho-Pereira, 2020). }\end{array}$ \\
\hline Awareness & $\begin{array}{l}\text { Awareness refers to being aware of others' activities, opinions, locations, and information they have (Rice } \\
\text { et al, 2017). }\end{array}$ \\
\hline Editability & $\begin{array}{l}\text { Editability allows individuals to craft and re-craft as much as they want the information or } \\
\text { communication before they post it and make it available for others (Rice et al., 2017; Treem \& Leonardi, } \\
\text { 2013). }\end{array}$ \\
\hline Identity creation & $\begin{array}{l}\text { Identity creation refers to users creating their profile with self-generated content and others' content, } \\
\text { crafting their identities, and assuming different roles (Koehler \& Vilarinho-Pereira, 2020). }\end{array}$ \\
\hline Ownership & $\begin{array}{l}\text { Ownership allows students to create their own content by expressing their ideas, making sense of what } \\
\text { they are learning, and showcasing what they developed while embracing diverse roles (Koehler \& Ertmer, } \\
\text { 2016; Koehler et al., 2017). }\end{array}$ \\
\hline Persistence & $\begin{array}{l}\text { Persistence refers to the online information that is recorded, archived, and kept accessible in its original } \\
\text { form (boyd, 2014; Treem \& Leonardi, 2013). }\end{array}$ \\
\hline Pervasiveness & Pervasiveness refers to the ability to communicate anytime and anywhere (Rice et al., 2017). \\
\hline Searchability & $\begin{array}{l}\text { Searchability is the possibility to have access to content and people through search tools (boyd, 2014; Rice } \\
\text { et al., 2017). }\end{array}$ \\
\hline Self-presentation & $\begin{array}{l}\text { Self-presentation is related to users' possibility to manage their identity by maintaining relations with } \\
\text { others, letting their information and comments available, and customize their social media profile } \\
\text { according to their preferences (Rice et al., 2017). }\end{array}$ \\
\hline Spreadability & Spreadability refers to "the ease with which content can be shared" (boyd, 2014, p. 11). \\
\hline Visibility & $\begin{array}{l}\text { Visibility is related to the fact that social media allow users to make visible their information, connections, } \\
\text { and actions (e.g., creations, comments, opinions, choices, network connections) for anyone they allow to } \\
\text { have access to their social media profile (boyd, 2014; Treem \& Leonardi, 2013). }\end{array}$ \\
\hline
\end{tabular}




\section{CREATIVITY}

According to Runco and Jaeger (2012), the standard definition of creativity comprises two criteria: originality (also called novelty, unusualness, or uniqueness) and effectiveness (also called usefulness, fit, or appropriateness). Considering this definition, creativity can be defined as the creation of an original product, idea, or service that is also effective to the society which the creator is a part of (Hennessey \& Amabile, 2010).

Although creativity is commonly perceived as involving big discoveries and people considered geniuses, the Four CModel of Creativity provides a different conceptualization of creativity (Kaufman \& Beghetto, 2009). In this model, the authors described four different levels of creativity: mini-c, little-c, Pro-c, and Big-C. Mini-c creativity reflects one's learning process and involves constructing personal knowledge and understanding in specific contexts. Little-c creativity is the type displayed by nonexperts on a daily basis when doing something creative. Pro-c creativity is displayed by professionals in a creative area. Big- $\mathrm{C}$ creativity reflects the work of individuals who are considered eminent for making creative contributions to a field.

To help foster their students' creativity, educators should be aware of these levels of creativity. Teaching practices can influence learners' mini-c and little-c creativity initially and later skills in these areas can be transformed into a Pro-c or Big- $\mathrm{C}$ creativity. To progress from one creativity level to the next, different elements are useful. For instance, to go from a mini-c to little-c level of creativity, feedback is essential; practice can take one from little-c to Pro-c creativity; and to reach Big-C status time is an important factor (Beghetto \& Kaufman, 2014).

According to Amabile (1996), a social environment can represent both positive and negative influences on creativity. In her studies, Amabile identified that a positive environment to creativity values individuals' autonomy, provides sufficient resources, recognizes the importance of their work and their competence, offers optimal levels of challenge, and presents sufficient structure to carry out the activity. The negative environment to creativity restricts freedom of opinion, establishes arbitrary and unreachable deadlines, prioritizes competition instead of collaboration, and uses critical evaluations, which connote the disqualification of the individual.

Beghetto and Kaufman (2014) discussed strategies that can be used in the classroom to develop a creativity-supportive learning environment. These include activities in which students can present multiple and divergent ideas, redefine problems, have choice and opportunities to explore, work on meaningful school projects, collaborate with other students and outside experts, and have teachers who model and support students' creative endeavors.

\section{SOCIAL MEDIA AND CREATIVITY}

The connection between social media and creativity, especially among youth, is increasingly being explored by researchers. Research reveals that youth's use of social media, regardless of 
race or class, continues to increase (Rideout, Foehr, \& Roberts, 2010) and that this use includes consuming and producing media (Peppler, 2013). Jenkins, Purushotma, Weigel, Clinton, and Robison (2009) labeled this activity as "participatory culture." The wide availability of tools that youth can use to create artifacts and share them on the internet makes engaging in the production of media easy (Peppler, 2013). According to the author, this was something that only or mainly experts and professionals would have done prior to the advent of social media. For instance, many youth become influencers by posting creative content on social media platforms, such as YouTube or Instagram, among others. As social media continue to evolve and become a common part of daily life, researchers are calling for additional exploration into how social media platforms offer "important sites of creativity" (Peppler, 2013, p. 194). By engaging with media and other information on social media platforms, youth also have opportunities to learn about culture and art (Peppler, 2010).

Social media, when used as educational tools, also have the potential to foster creativity (e.g., Ferguson, 2011; Jang, 2009), by creating "the potential to open up classroom experiences, making them more learner centered and expanding the potential content base of the class" (Dennen, 2018, p. 239). Similar to other digital technologies, social media can be used by students and teachers to stimulate imaginative expression, autonomy, collaboration, and originality (Loveless, 2007). However, teachers and instructors must also be attentive to the potential barriers social media can impose on creativity. Runco (2015) emphasized the incompatibility between the extrinsic orientation (e.g., likes, visibility, pressure to convey) of social media and "the unconventional lines of thought, and intrinsic nature of the creative process" (Conclusion section, para. 5). According to the author, one possibility to avoid the detrimental influence of extrinsic factors to creativity is to use social media during the implementation phase, when feedback from others is required, and avoid use in the early stages of the creative process, since judgment from others can inhibit the exposure of original thoughts.

\section{PURPOSE}

Although much potential exists for using social media to facilitate creativity in learners, the intersection of these areas remains an area that needs additional consideration. As social media are readily available to both teachers and students and offer specific affordances that can boost creativity, much potential exists for using these tools to enhance teaching and learning efforts. Therefore, to support the intentional use of social media to facilitate creativity, the purpose of this study was to review literature considering the use of social media in formal learning environments and their relationship to foster student creativity. The following two research questions were addressed: (a) how are social media being used in formal learning environments to foster student creativity? and (b) what are the social media affordances for creativity development? By exploring 
previous research in these areas, we can gain insight into how educators and researchers are exploring these topics and offer suggestions for guiding future research in meaningful ways.

\section{METHOD}

A systematic review of the literature on social media and their relationship to creativity was conducted. Five databases were used in this systematic review: Academic Search Premier, Education Full Text, Education Source, ERIC, and PsychINFO. The search was limited to articles published between 2010 and 2020 and the following descriptors were used in the search: Creativ* (AB) AND ("Social media" OR "Web 2.0" OR "Social networking sites" OR Wikis OR Blogs OR "Electronic discussion groups" OR "Online discussion forum" OR Podcasting OR Microblogs OR "Media sharing" OR Facebook OR Twitter OR Instagram OR YouTube) AND Education*. Table 2 includes the criteria for inclusion and exclusion used to screen abstracts and full texts that were searched through the databases. These criteria were established to guarantee that the articles presented in this literature review would be pertinent to the purpose of this study.

Table 2. Inclusion and Exclusion Criteria

\begin{tabular}{ll}
\hline \multicolumn{1}{c}{ Inclusion Criteria } & \multicolumn{1}{c}{ Exclusion Criteria } \\
\hline Empirical studies & Conceptual pieces, theoretical studies, literature reviews \\
\hline Quantitative, qualitative, or mixed-methods & No systematic data collection nor analysis \\
\hline $\begin{array}{l}\text { Creativity was mentioned as one outcome of the use of social } \\
\text { media }\end{array}$ & $\begin{array}{l}\text { Studies that classified the social media as creative, but did not } \\
\text { mention any outcome related to creativity }\end{array}$ \\
\hline Participants from K-12 education, Undergraduate, Graduate & Participants who are not students \\
\hline $\begin{array}{l}\text { Formal or traditional learning environments } \\
\text { Social media were implemented for an instructional-related } \\
\text { purpose }\end{array}$ & $\begin{array}{l}\text { Training, professional development, informal education, or } \\
\text { camp contexts }\end{array}$ \\
\hline
\end{tabular}

Social media can be "commercial" or created by the researcher or teacher

No social media were evaluated in the study

Language of the articles: English

Language of the articles: Not English

Note. K-12 education is an expression used in United States to refer to the school grades from kindergarten to $12^{\text {th }}$ grade. K-12 consists of three stages: elementary school, middle school, and high school. These are stages prior to college.

Figure 1 captures the PRISMA flowchart summarizing each phase of the identification and screening process. First, a search in the selected databases was conducted using the descriptors previously described. A total of 1,124 articles were found, and 483 duplicates were removed. Next, the lead researcher read the abstracts of the 641 remaining articles and selected 97 articles that met the 
inclusion criteria. In this phase, the other two researchers separately reviewed $5 \%$ of the total number of abstracts, and the inter-coder-reliability agreement was checked ( $93 \%$ agreement). The three researchers discussed the points of disagreement and reached a consensus. After reading the full text of 95 articles (two articles were not available in full text), 27 articles met the inclusion criteria and were selected for further analysis. An outside reviewer, who was a researcher from the creativity and talent development field, was consulted if the lead researcher was unsure if an article met the criteria.

In order to examine the uses and affordances of social media for creativity development in formal learning environments, the following information was extracted from the articles: (a) category of social media; (b) individual using the social media (e.g., academic level, grouping); (c) discipline and topic of study; (d) focus of use of social media; and (e) affordances of social media. The analyses focused primarily on the method, procedures for implementation of social media, results, and discussion of the articles.

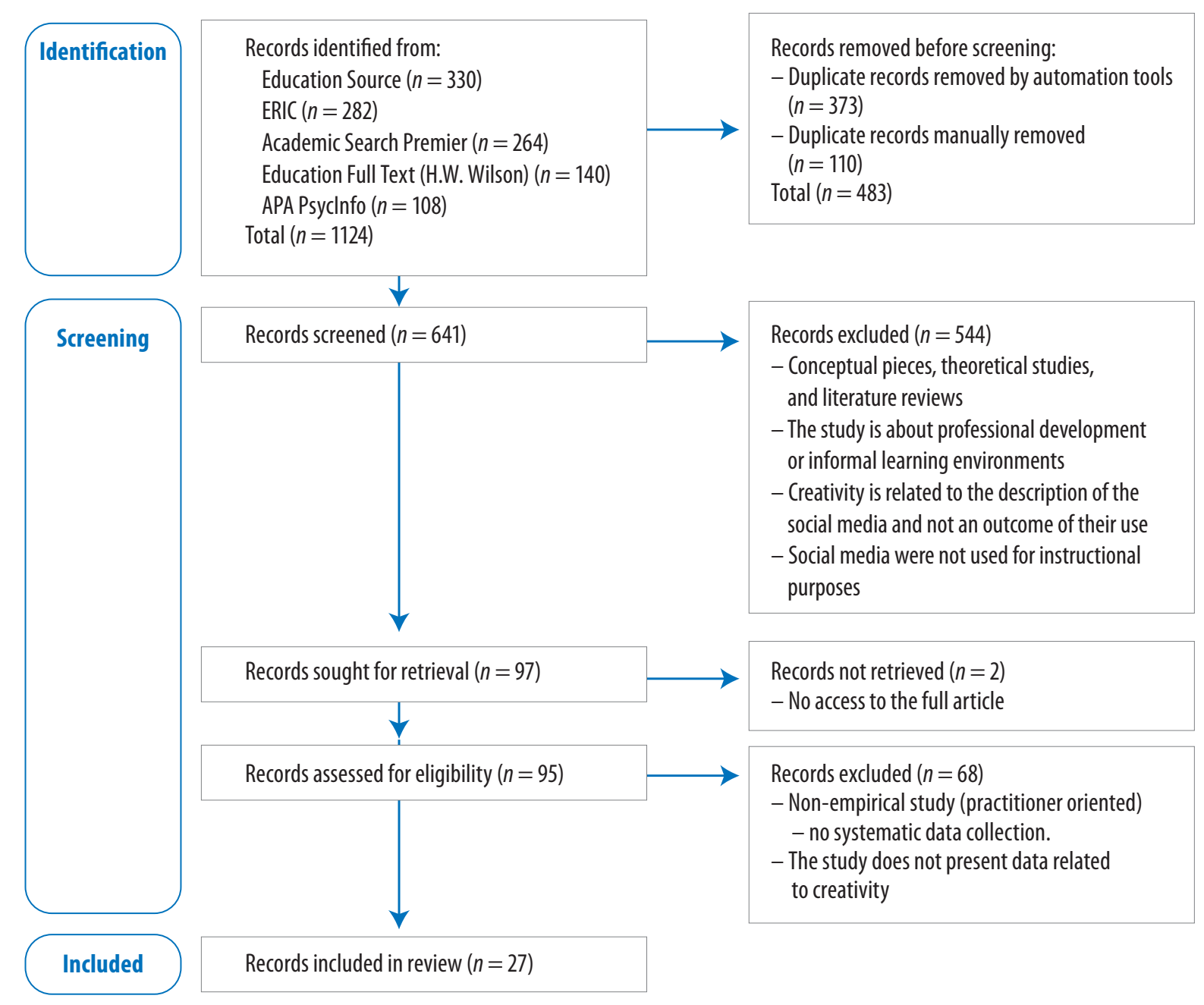

Figure 1. PRISMA Flowchart with the descriptions of each phase of the identification and screening process 


\section{DESCRIPTION OF SELECTED STUDIES}

In order to better understand the selected studies, information on the research methods and results of each study was extracted. The majority of the studies $(n=12)$ used qualitative methods, followed by quantitative methods $(n=10)$, and mixed-methods $(n=5)$. The results, in general, showed that social media enhanced student creativity in some way, with the exception of one mixed-method study (Bakla, 2020), in which participants did not think that social media promoted creativity. Worth noting, in most of the studies, creativity was reported from the participants' perspective without a scientific or traditional definition of creativity. For example, in Green, Inan, and Maushak (2014), participants mentioned that they experienced "creative freedom" while creating vidcasts, which was interpreted as social media enhancing creativity by the researchers. In another study, Daud and Khalid (2014) developed a questionnaire where an item related to social media use ("weblogs allow me to express my views freely") had the highest mean (p. 127). The authors interpretated this as "students appreciated the usage of weblogs as weblogs allow them to express their views freely, through which their critical and creative thinking is developed" (p. 126). Crilly and Kayyali (2020) used a survey to access students' perceptions about the use of Facebook as an educational tool. In the results, creativity was one of the most emphasized skills by students when asked to identify what they gained from using social media to complete the assignment. A description of research methods and results for selected studies is included in Table 3.

\section{Table 3. Description of Research Methods and Results of Each Study}

\begin{tabular}{llll}
\hline \multicolumn{1}{c}{ Authors (Year) } & $\begin{array}{c}\text { Research } \\
\text { Methods }\end{array}$ & Participants & \multicolumn{1}{c}{ Results Related to Creativity } \\
\hline $\begin{array}{l}\text { Bolden \& Nahachewsky } \\
\text { (2015) }\end{array}$ & Qualitative & 9 students & Participants discussed the creative potential of making a podcast. \\
\hline $\begin{array}{l}\text { Chen, Jang, \& Chen } \\
\text { (2015) }\end{array}$ & Qualitative & 9 students & Wikis helped participants generate creative instructional strategies. \\
\hline $\begin{array}{l}\text { Cook Major, Warwick, } \\
\text { \& Vrikki (2020) }\end{array}$ & Qualitative & 3 students & $\begin{array}{l}\text { Social media allowed students in a creative process of co- } \\
\text { construction and to generate new ideas. }\end{array}$ \\
\hline $\begin{array}{l}\text { Galen \& } \\
\text { Khodabandehlo0 (2016) }\end{array}$ & Qualitative & 20 students & $\begin{array}{l}\text { Most participants stated that blogging in Linkedln fostered their } \\
\text { creativity. }\end{array}$ \\
\hline Green et al. (2014) & Qualitative & 8 students & $\begin{array}{l}\text { Participants valued the creative freedom they had while creating } \\
\text { vidcasts. }\end{array}$ \\
\hline Kivunja (2015) & Qualitative & 82 students & $\begin{array}{l}\text { Social media provided opportunities to engage with and develop } \\
\text { 21st century skills (i.e., critical thinking, collaboration, creativity, } \\
\text { and communication). }\end{array}$ \\
\hline Magnuson (2013) & Qualitative & 17 students & $\begin{array}{l}\text { Participants found Glogster and Prezi to be creatively stimulating. } \\
\text { They did not mention creativity when discussing their use of } \\
\text { PBworks and Diigo. }\end{array}$ \\
\hline
\end{tabular}




\begin{tabular}{|c|c|c|c|}
\hline Authors (Year) & $\begin{array}{l}\text { Research } \\
\text { Methods }\end{array}$ & Participants & Results Related to Creativity \\
\hline $\begin{array}{l}\text { Meschoulam et al. } \\
\text { (2019) }\end{array}$ & Qualitative & 118 students & $\begin{array}{l}\text { Most of the participants mentioned the creativity exercises used in } \\
\text { this study. }\end{array}$ \\
\hline $\begin{array}{l}\text { Sari, Sarana, Dardjito, } \\
\& \text { Azizah (2020) }\end{array}$ & Qualitative & 79 students & $\begin{array}{l}\text { The YouTube platform allowed students to deliver information } \\
\text { creatively. }\end{array}$ \\
\hline $\begin{array}{l}\text { Surgenor, McMahon- } \\
\text { Beattie, Burns, } \\
\text { \& Hollywood (2016) }\end{array}$ & Qualitative & 108 students & $\begin{array}{l}\text { Podcasts helped students develop their skills through interpretive } \\
\text { and integrative creativity. }\end{array}$ \\
\hline $\begin{array}{l}\text { Widodo, Budi, } \\
\text { \& Wijayanti (2016) }\end{array}$ & Qualitative & 37 students & Facebook helped students express their ideas creatively. \\
\hline Wood (2012) & Qualitative & 14 students & $\begin{array}{l}\text { Blogs provided a space for student teachers to develop creative } \\
\text { ideas to be used in their teaching. }\end{array}$ \\
\hline $\begin{array}{l}\text { Alias, Siraj, Azman, } \\
\text { Daud, \& Hussin (2013) }\end{array}$ & Quantitative & 80 students & $\begin{array}{l}\text { The Isman Instructional Design Model was found to be "suitable } \\
\text { in designing and developing Facebook based learning to enhance } \\
\text { creativity among Islamic Studies students." (p. 60) }\end{array}$ \\
\hline $\begin{array}{l}\text { Auttawutikul, } \\
\text { Wiwitkunkasem, } \\
\text { \& Smith (2014) }\end{array}$ & Quantitative & 41 students & $\begin{array}{l}\text { Blogs enhanced group learning and creativity and provide an } \\
\text { environment in which students can show individual creativity. }\end{array}$ \\
\hline Chang (2019) & Quantitative & 116 students & $\begin{array}{l}\text { Experimental group (cloud-based m-learning) had higher scores for } \\
\text { ellaboration, novelty, and usefulness. }\end{array}$ \\
\hline Daud \& Khalid (2014) & Quantitative & 68 students & $\begin{array}{l}\text { Participants indicated that the blogs allowed them to express their } \\
\text { views freely and thus develop their creative thinking. }\end{array}$ \\
\hline $\begin{array}{l}\text { Garcia-Garcia, Chulvi, } \\
\text { \& Royoca (2017) }\end{array}$ & Quantitative & 97 students & $\begin{array}{l}\text { Findings support the hypothesis that virtual team-working } \\
\text { enhances creativity. }\end{array}$ \\
\hline Crilly \& Kayyali (2020) & Quantitative & 78 students & $\begin{array}{l}\text { Participants stated that they developed creativity skills by using } \\
\text { social media to deliver a public health campaign. }\end{array}$ \\
\hline Hargrove (2013) & Quantitative & $\begin{array}{l}\sim 120 \\
\text { students }\end{array}$ & $\begin{array}{l}\text { The use of social media enhanced and maintained students' } \\
\text { creative thinking abilities. }\end{array}$ \\
\hline $\begin{array}{l}\text { Liu, Lu, Wu, \& Tsai } \\
\text { (2016) }\end{array}$ & Quantitative & 53 students & $\begin{array}{l}\text { The stories created by the peer review (treatment) group had better } \\
\text { content quality, but there was no difference in technical quality, } \\
\text { creativity self-efficacy, and creativity levels between the treatment } \\
\text { and control groups. }\end{array}$ \\
\hline Paraskeva et al. (2015) & Quantitative & 44 students & $\begin{array}{l}\text { Students experienced increases in fluency, flexibility, elaboration, } \\
\text { and originality, suggesting that the use of Wikispaces through De } \\
\text { Bono's Six Thinking Hats method "could support learners to engage } \\
\text { in and bolster their creative thinking." (p. 15) }\end{array}$ \\
\hline $\begin{array}{l}\text { Stolaki \& Economides } \\
\text { (2018) }\end{array}$ & Quantitative & 90 students & $\begin{array}{l}\text { Students experienced statistically significant increases in fluency, } \\
\text { flexibility, elaboration, and originality. Facebook usage or ICT } \\
\text { knowledge prior to the study was not related to creativity } \\
\text { enhancement. The authors found that student creativity had } \\
\text { a positive link to academic achievement and ICT knowledge. }\end{array}$ \\
\hline
\end{tabular}




\begin{tabular}{llll}
\hline \multicolumn{1}{c}{ Authors (Year) } & $\begin{array}{l}\text { Research } \\
\text { Methods }\end{array}$ & Participants & \multicolumn{1}{c}{ Results Related to Creativity } \\
\hline Bakla (2020) & $\begin{array}{l}\text { Mixed- } \\
\text { method }\end{array}$ & 27 students & $\begin{array}{l}\text { Activities created by some participants were simple and with } \\
\text { limited originality and they did not think that using social media } \\
\text { promoted creativity. }\end{array}$ \\
\hline Bull \& Adams (2012) & Mixed- & 42 students & $\begin{array}{l}\text { Students' survey responses indicated that Twitter promoted } \\
\text { creativity. }\end{array}$ \\
\hline $\begin{array}{l}\text { Frydenberg \& Andone } \\
\text { (2016) }\end{array}$ & $\begin{array}{l}\text { Mixed- } \\
\text { method }\end{array}$ & 68 students & $\begin{array}{l}\text { The six-second constraint of micro-videos encouraged participants } \\
\text { to demonstrate creativity. }\end{array}$ \\
\hline Helwa (2020) & $\begin{array}{l}\text { Mixed- } \\
\text { method }\end{array}$ & 60 students & \begin{tabular}{l} 
Students experienced increase in creative reading skills. \\
\hline Novak \& Mulvey (2020)
\end{tabular} \\
$\begin{array}{l}\text { Mixed- } \\
\text { method }\end{array}$ & 10 students & $\begin{array}{l}\text { Students' perceptions of factors related to creativity that affect } \\
\text { the design thinking process, such as shaping their external } \\
\text { environment to help them be more creative and finding sources of } \\
\text { creative inspiration, increased. }\end{array}$ \\
\hline
\end{tabular}

\section{RESULTS AND DISCUSSION}

\section{Description of Use}

In the following subsections, results of the analysis are shared related to the category of social media being used, individual using the social media, the discipline and topics taught with social media, and what students did with social media.

\section{Category of Social Media Being Used}

Across the 27 articles selected for this literature review, a variety of social media tools were used for instructional purposes. The social media investigated in these studies can be classified into 10 categories. Social networking sites (e.g., Facebook and Google+) were considered in eight studies. Blogs (e.g., WordPress) were explored in seven studies. Wikis (e.g., PBworks), microblogging (e.g., Twitter and Talkwall), podcasts (podcast application used were not indicated), and media sharing (e.g., YouTube and Vine) were each researched in three studies. Collaborative authoring (e.g., Glogster and Prezi) and instant messaging (e.g., WhatsApp and Telegram) were each explored in two studies. One study investigated idea mapping (e.g., Mindomo), and another study investigated social bookmarking (e.g., Diigo). In some articles, more than one social-media platform was investigated; thus, the sum of studies mentioned regarding the categories of social media used is more than 27 (number of articles analyzed in the present study).

Across these studies, multiple social media applications were investigated as related to creativity outcomes, such as originality, fluency, flexibility, creativity self-efficacy, students' perception about their experience and production, and other outcomes the authors associated 
with creativity. Although all of the digital platforms have defining characteristics of social media, each one includes different features that can favor the expression of creativity in different areas such as writing (e.g., Widodo et al., 2016), visual presentation (e.g., Magnuson, 2013), or speaking skills (e.g., Sari et al., 2020). This suggests that students were able to express themselves in a variety of forms. At the same time, with numerous social media applications available, some social media were not considered that could arguably promote creativity in learners (e.g., Instagram, SnapChat). This suggests that education and educational research sometimes lag behind trends in the digital world and that teachers miss opportunities to engage students in creative endeavors by ignoring social media platforms that are widely used by their students. However, understandably, researchers and teachers likely favor social media that are familiar and well-established.

\section{Individual Using the Social Media}

Reviewing the selected studies revealed that social media are being used across academic levels: 13 studies were conducted with undergraduate students, 8 studies considered the experiences of K-12 students, and, in 6 studies, the social media were used by graduate students. Additionally, in some studies, the participants were pre- or in-service teachers using social media with the purpose to prepare themselves to use these tools with their students in the future (undergraduate, $n=3$; graduate, $n=2)$.

An important consideration of instructional social media use includes how students are grouped (e.g., individually, in pairs, or in groups) to accomplish the tasks and goals established by the teacher. That is, "each type of grouping has its own logistical and process concerns that must be considered when planning instruction" (Reigeluth \& Moore, 1999, p. 61). In most of the studies, students worked individually to complete their work $(n=14)$. For example, undergraduate students from a design course created an individual blog in which they reflected on their design thinking processes (Hargrove, 2013). This does not necessarily mean that students were not interacting with each other through the social media. In many cases, students were required to comment on their peers' work (e.g., Kivunja, 2015; Widodo et al., 2016) or communicate with peers, interact with the instructor, share information (e.g., Bull \& Adams, 2012; Meschoulam et al., 2019), or even exchange ideas and perspectives (e.g., Auttawutikul et al., 2014). Very few social media were used by students in isolation (e.g., Bolden \& Nahachewsky, 2015; Frydenberg \& Andone, 2016; Surgenor et al., 2016). For example, in one study, middle school students used podcasts to learn about cooking from experienced people before they started experimenting with new recipes (Surgenor et al., 2016). In this situation, the goal of the instruction was to have social media as a medium of information versus a tool to facilitate interaction. Although the social aspect of the tool was not emphasized, students had a unique experience of learning from experts.

In the other 10 studies, students were required to work in groups using social media to accomplish their task. In some cases, social media provided a medium for communication, but not a medium for sharing the product created by students (e.g., Garcia-Garcia et al., 2017). In other cases, social media offered learners a space to communicate, collaborate, create, and share their 
work (e.g., Paraskeva et al., 2015). In another instance, the social media application was also used only as a medium for sharing students' work, and not allowing the possibility to communicate or collaborate using the features of the social media (e.g., Sari et al., 2020).

In only one study, graduate students were assigned to work in pairs (Wood, 2012). These learners were being prepared to qualify as geography teachers, and, in pairs, they collaborated to create a blog discussing a geographic concept.

In the remaining two studies, students had the experience of working individually and in groups. In Chen et al.'s (2015) study, learners first created their project individually using a wiki, so they could familiarize themselves with the social media. In a second phase, they used the wiki in groups to collaborate and create a project. In Magnuson's (2013) study, students used four different social media tools at different points in a course and for different tasks. Glogster, Diigo, and Prezi were used individually to achieve the goal proposed by the instructor (create an electronic poster, add web resources to the course library, and develop a presentation, respectively). In groups, students created a wiki page with information about a learning theory (Magnuson, 2013).

Another area of interest when analyzing the use of digital technology for educational purposes is to identify who is using the tool. In many cases, even with technology, the pedagogy continued as teacher-centered, in which the teacher controls the tool, and students passively receive information through a new medium. However, in most of the studies selected for this literature review $(n=19)$, the student was actively using the social media to create, collaborate, communicate, and share information to support their own creation. This learner-centered use of social media allowed for more freedom, autonomy, and independence, which are factors related to the development of creativity in the classroom (Amabile, 1996). This also helps students develop self-regulation and promotes peer accountability and feedback. In the other eight studies, both teacher and students used the social media. Regardless of who was using social media, in the studies included in this review, teachers were the ones who selected which types of social media were used and provided support for such use (See Table 4 for a summary of the social media used and the individual using them).

Table 4. Information about Social Media Use Presented by Academic Level

\begin{tabular}{llll}
\hline \multicolumn{1}{c}{ Author (Year) } & \multicolumn{1}{c}{ Social Media } & \multicolumn{1}{c}{ Grouping } & Who is Using? \\
\cline { 2 - 4 } & K-12 Level & & \\
\hline Alias et al. (2013) & Facebook & Individually & Both \\
\hline Bakla (2020) & Blogs (WordPress) & Individually & Student \\
\hline Bull \& Adams (2012) & Twitter & Individually & Both \\
\hline Cook et al. (2020) & Talkwall (microblogging tool) & Groups & Student \\
\hline Green et al. (2014) & Vidcast & Groups & Student \\
\hline Liu et al. (2016) & Web 2.0 Storytelling platform & Individually & Student \\
\hline Surgenor et al. (2016) & Podcasting & Individually & Student \\
\hline Widodo et al. (2016) & Facebook & Groups & Both \\
\hline
\end{tabular}




\begin{tabular}{llll}
\hline \multicolumn{2}{c}{ Author (Year) } & \multicolumn{1}{c}{ Social Media } & Grouping \\
\hline \multicolumn{3}{c}{ Undergraduate Level } & Who is Using? \\
\hline Auttawutikul et al. (2014) & Blog & Individually & Student \\
\hline Bolden \& Nahachewsky (2015) & Podcasting & Individually & Student \\
\hline Chang (2019) & Facebook, Mindomo, and Cubie & Groups & Both \\
\hline Daud \& Khalid (2014) & Blog & Individually & Student \\
\hline Frydenberg \& Andone (2016) & Vine, YouTube & Individually & Student \\
\hline Garcia-Garcia et al. (2017) & Google+ & Groups & Student \\
\hline Hargrove (2013) & Blog & Individually & Student \\
\hline Helwa (2020) & WhatsApp, Facebook, and Telegram & Individually & Both \\
\hline Kivunja (2015) & Google Circles Learning Communities & Groups & Both \\
\hline Meschoulam et al. (2019) & Twitter & Individually & Both \\
\hline Paraskeva et al. (2015) & Wikispaces & Groups & Student \\
\hline Sari et al. (2020) & YouTube & Groups & Student \\
\hline Stolaki \& Economides (2018) & Facebook & Groups & Both \\
\hline & Graduate Level & & \\
\hline Chen et al. (2015) & Wiki & Individually and groups & Student \\
\hline Galen \& Khodabandehlo0 (2016) & Blogs (Linkedln) & Individually & Student \\
\hline Crilly \& Kayyali (2020) & Facebook & Groups & Student \\
\hline Magnuson (2013) & Glogster, PBworks, Diigo, Prezi & Individually and groups & Student \\
\hline Novak \& Mulvey (2020) & Blogs & Individually & Student \\
\hline Wood (2012) & Blogs & Pairs & Student \\
\hline
\end{tabular}

Note. Both $=$ Teacher and Student.

\section{Disciplines and Topics Taught with Social Media}

Educators in the reviewed studies implemented social media in different disciplines to teach a variety of topics that can be categorized as follows: cooking (e.g., Surgenor et al., 2016), design (e.g., Garcia-Garcia et al., 2017), digital literacy (e.g., Frydenberg \& Andone, 2016), education (e.g., Kivunja, 2015), English as a foreign language (EFL; e.g., Green et al., 2014), public health (e.g., Crilly \& Kayyali, 2020), information systems (e.g., Stolaki \& Economides, 2018), international relations (e.g., Meschoulam et al., 2019), language (e.g., Cook et al., 2020), marketing (e.g., Galen \& Khodabandehloo, 2016), religion (e.g., Alias et al., 2013), and social studies (e.g., Bull \& Adams, 2012). This indicates that social media are versatile and can be applied in different scenarios, especially to create more authentic learning environments, such as when undergraduate students used Twitter as part of a negotiation simulation in which they played the role of a diplomat (e.g., Meschoulam et al., 2019). Table 5 includes the disciplines and the topics taught using social media in each study.

Table 5. Disciplines and Topics Taught with Social Media in each Study

\begin{tabular}{lll}
\hline \multicolumn{1}{c}{ Authors (Year) } & \multicolumn{1}{c}{ Discipline } & \multicolumn{1}{c}{ Topic } \\
\hline Surgenor et al. (2016) & Family and Consumer Sciences & Basic cooking skills; creative thinking in the kitchen \\
\hline Hargrove (2013) & Design & $\begin{array}{l}\text { Metacognitive skills as a part of the development of } \\
\text { creative thinking ability (Design studio) }\end{array}$ \\
\hline
\end{tabular}




\begin{tabular}{|c|c|c|}
\hline Authors (Year) & Discipline & Topic \\
\hline Novak \& Mulvey (2020) & Instructional Technology & Design thinking \\
\hline Garcia-Garcia et al. (2017) & Design Engineering & Graphic design \\
\hline Chang (2019 & Design & Digital image design \\
\hline Frydenberg \& Andone (2016) & $\begin{array}{l}\text { Information Technology and } \\
\text { Technologies of Multimedia }\end{array}$ & Basic digital literacy skills / technology topics and concepts \\
\hline Daud \& Khalid (2014) & Educational Technology & ICT literacy \\
\hline Paraskeva et al. (2015) & Educational Psychology & Internet safety and learning theories \\
\hline Auttawutikul et al. (2014) & Educational Technology & Production of creative educational media \\
\hline Chen et al. (2015) & Teacher Education & $\begin{array}{l}\text { Learning theories, teaching strategies, data collection, and } \\
\text { course design through action research }\end{array}$ \\
\hline Magnuson (2013) & $\begin{array}{l}\text { Library and Information } \\
\text { Science }\end{array}$ & $\begin{array}{l}\text { Theories of teaching and learning, educational technology, } \\
\text { course design, and various information literacy standards }\end{array}$ \\
\hline Kivunja (2015) & Teacher Education & Planning and assessing for active learning \\
\hline Bolden \& Nahachewsky (2015) & Music Education & Self-exploration within music teacher education \\
\hline Green et al. (2014) & English as a Foreign Language & Reading \\
\hline Sari et al. (2020) & Psychology & EFL speaking skills \\
\hline Bakla (2020) & Turkish Learners of English & Reading skills \\
\hline Widodo et al. (2016) & English as a Foreign Language & Poetry writing \\
\hline Helwa (2020) & English as a Foreign Language & Creative reading \\
\hline Crilly \& Kayyali (2020) & Pharmacy & Pharmacy students' decision making in public health \\
\hline Stolaki \& Economides (2018) & Information Systems & Not specified - Information systems topics \\
\hline Meschoulam et al. (2019) & International Relations & Negotiation about international issues \\
\hline Cook et al. (2020) & English & $\begin{array}{l}\text { MASTS (metaphor, alliteration, simile, triple, senses) and } \\
\text { animals }\end{array}$ \\
\hline Liu et al. (2016) & Chinese Literacy & Storytelling activity \\
\hline Galen \& Khodabandehloo (2016) & International Marketing & International marketing and global development \\
\hline Alias et al. (2013) & Islamic Studies & Writing, problem solving, and producing missionary motto \\
\hline Bull \& Adams (2012) & Social Studies & $\begin{array}{l}\text { Intentions of the Founding Fathers surrounding the Bill of } \\
\text { Rights }\end{array}$ \\
\hline Wood (2012) & Geography & Geographic concepts \\
\hline
\end{tabular}

\section{What Students Did with Social Media}

Among the studies, social media were selected to achieve different tasks. The major tasks completed by students using social media can be categorized in at least three ways: creating, communicating, and collaborating. Additionally, in some instances, learners completed more than one of these tasks.

Creating. In most of the studies, the tasks that students had to accomplish involved the creation of a product. These products took on a variety of forms, showing the versatility of social media as development tools. Through the creation process, students were able to express themselves by presenting their ideas, perceptions, and experiences. This type of task aligns with strategies proposed by Beghetto and Kaufman (2014) to promote a creativity-supportive learning environment. 
Students used social media to create in many ways. For example, students created videos about technology concepts and shared via Vine (Frydenberg \& Andone, 2016) or practiced their English-speaking skills by posting videos on YouTube (Sari et al., 2020). Blog posts were created by graduate students to discuss geographic concepts (Wood, 2012) and by pre-service teachers to write about teaching and learning in their area of specialization (Daud \& Khalid, 2014). In another instance, a storytelling platform created by the researchers was used by elementary students to develop stories about adventures to Mars and saving a forest (Liu et al, 2016). In-service teachers in a graduate-level course designed their lesson plans and developed their course material using wikis (Chen et al., 2015). In another study, pre-service teachers created different products (e.g., concept maps and presentations) using wikis in order to discuss internet safety (Paraskeva et al., 2015). Facebook was used by middle school students to write poems (Widodo et al., 2016). Blogs were used by students to write reflections on their design thinking process (Hargrove, 2013; Novak \& Mulvey, 2020), and podcasts were recorded by students to capture self-reflections within music teacher education (Bolden \& Nahachewsky, 2015). Glogster and Prezi were used to develop posters and presentations, respectively (Magnuson, 2013). Thus, social media also provided students with a variety of features (e.g., capturing, editing, and sharing video or images) that students can use to create and publish their creations, which also affects the learning experience.

Communicating. Communication among students and between students and their teacher also comprised a key task that students were required to accomplish in most of studies. The communication took different forms and had a variety of purposes. Students communicated among themselves and with teachers to receive course announcements and to ask questions about course assignments (e.g., Stolaki \& Economides, 2018), to give and receive feedback (e.g., Kivunja, 2015; Widodo et al., 2016), to share and access content and information (e.g., Alias et al., 2013; Bull \& Adams, 2012), to share personal creations and gain access to others' creations (e.g., Chang, 2019; Liu et al., 2016), to promote personal creations (e.g., Crilly \& Kayyali, 2020; Sari et al., 2020), and to communicate ideas, perceptions, and experiences (e.g., Galan \& Khodabandehloo, 2016; Hargrove, 2013). Communicating allowed students to give and receive feedback which is essential for students to develop little-c creativity (Beghetto \& Kaufman, 2014).

Collaborating. The tasks that students were required to accomplish also involved collaboration. Google+ (e.g., Garcia-Garcia et al., 2017), wikis (e.g., Chen et al., 2015; Paraskeva et al., 2015), Mindomo and Cubie (e.g., Chang, 2019), and Facebook (e.g., Widodo et al., 2016) allowed students to virtually collaborate in order to achieve a shared goal. While collaborating, students are able to learn with each other and enrich their production with different perspectives. Promoting collaboration among students is a way of fostering creativity in the classroom (Amabile, 1996, Beghetto \& Kaufman, 2014).

Although students were required to work in groups to complete a task in other studies as well, the collaboration part possibly took place face-to-face or through another digital technology not described by the researchers, probably because they did not have control over that aspect or it 
was not the focus of their research. For example, in one study, the instructor facilitated a "Creativity Challenge" on Facebook. As a part of this process, a team of students created their questionnaire, sent it initially to the instructor through email, and then posted the final questions on Facebook, announcing the challenge. Then, the other teams answered the questions and sent them to the instructor via email. The Facebook group created for this activity was not used for students to collaborate (Stolaki \& Economides, 2018). The choice of how the collaboration would take place (e.g., on social media or offline) in the studies is unclear. However, it appears to have no connection to the capabilities of social media (in general). In some studies, instructors might have decided to engage students in face-to-face collaboration because it was an option or students might have opt to use other social media or other features of the internet (e.g., email) to collaborate with their colleagues. Additionally, the features that allow for collaboration vary across different social media and, in some cases, the instructors limited the social media features to be used by students and controlled the purpose of using social media.

The three tasks (i.e., creating, communicating, and collaborating) showed that educators made use of the main characteristics of social media (e.g., create, share, collaborate, and interact; McCay-Peet \& Quan-Haase, 2016) while designing their instructions. In most studies, students were active "produsers" (Bruns, 2008). While communicating and collaborating, students were part of a community of learners in which they were able to build relationships and collective knowledge.

\section{Social Media Affordances for Creativity}

In the following subsections, results related to social media affordances for creativity are presented. Ownership, association, and visibility were identified as social media affordances for creativity in the studies.

\section{Ownership}

With social media, the possibilities of creation are multiple; and students can collaborate with their peers, while applying creativity (Oliver, 2010). In one study, undergraduate students collaborated virtually to develop creative digital image designs. For the author, the social media (Facebook, Mindomo, and Cubie) environment that allowed "real-time, free, equal, and criticismfree participation" was "beneficial for improving creative performance" (Chang, 2019, p. 42).

\section{Association}

Social media allow students to have access to unlimited and diverse perspectives, which can encourage different ways of thinking and favor divergent perspectives. This affordance is illustrated by a quote from one of the participants from Auttawutikul et al.'s (2014) study "The exchange of ideas with others gives us a broader perspective on the world. Perhaps we frame ourselves when we think alone" (p. 384). According to the authors, students' creativity was encouraged by the blogging environment, in which the association with other peers and their different ideas, perceptions, and 
experiences allowed the exchange of knowledge, different points of view, and totally new ways of approaching a situation.

\section{Visibility}

Visibility opens at least two avenues for students - promoting their creations and gaining access to their peers' creations. The opportunity to receive and give feedback (e.g., comments and likes), be praised for personal creations, and gain inspiration from others' work are some of the outcomes that relate to visibility. In Liu et al.'s (2016) study, the storytelling platform allowed students to create stories, share them with their peers, and review others' works. The group of students prompted to showcase their stories and receive feedback from their peers presented stories with higher quality content (e.g., transitions and edits, story planning and boarding, and accuracy of information) than the students who did not receive feedback. The peer review activity did not negatively affect students' creative self-efficacy. Both groups presented high levels of creative self-efficacy.

\section{CONCLUSION}

Social media are widely used in today's society, and research has shown their potential for use in formal educational environments. This paper reviewed literature considering the use of social media in education as related to creativity development. Specifically, this paper focuses on how social media have been used in formal learning environments to foster student creativity using the social media affordances for creativity development. The ultimate goal was to describe specific methods and uses of social media as part of the learning experiences leading to environments that facilitate creativity, as simply integrating social media in learning and instruction does not automatically result in increased levels of creativity.

Our analysis of the literature revealed 27 studies on a variety of social media platforms, involving all age groups/academic levels, and in multiple disciplines - from arts to technology. The studies used qualitative, quantitative, and mixed-methods, and the results predominantly indicate that social media afford creativity development. In this sense, arguably, social media, with the appropriate pedagogical methodology, can be successfully used as an educational tool to build an environment that promotes student creativity.

In most of the studies, participants created their own (individual) products and used social media for communication with others, commonly to provide feedback or share ideas and their creations. Although studies in which students were able to virtually collaborate were fewer, this type of task allowed students to exchange ideas and develop their creativity. This suggests that, by communicating or collaborating, the possibility to be in contact and interact with other colleagues and teachers through social media is beneficial for the development of creativity.

In most cases, social media were used by students only, giving them the autonomy to produce content, express their opinions, and share their experiences. In the majority of the studies, social 
media offered a medium in which students actively participated in their learning process. Learnercentered approaches using social media are aligned with strategies to foster creativity in the classroom. In this sense, while using social media for instructional purposes, giving students choice on how to present their products, allowing flexibility, and promoting exploration is important.

In the studies analyzed in this systematic literature review, three social media affordances were highlighted as related to creativity development: ownership, association, and visibility. Ownership allowed participants to create and showcase their own products, giving them a sense that they were part of a community of content creators. Association allowed participants to be exposed to different perspectives, and visibility allowed them to receive feedback from multiple sources and to improve their creations. In this sense, teachers and instructors might consider these affordances when designing instruction involving social media with the purpose to develop student creativity. One affordance related to creativity that was not highlighted in the studies is editability, which would have allowed participants to continuously elaborate on their ideas and enhance their products. A hypothesis that can be raised is that students might not associate elaborating their production with creativity, and, in this case, they would not identify the fact that social media affords editability as beneficial to their creative process.

Considering that social media are ever present in today's society, and creativity is considered a 21st Century skill that educators aim to develop in all students, the number of studies that made this connection between social media and creativity is relatively low $(n=27)$. Additionally, several of the studies reported students' perspectives of their creativity instead of using well-established definitions of creativity. Although these studies are valuable and reflect how students perceive social media as a place that provides a climate of autonomy and flexibility, additional research that uses validated instruments to measure creativity is necessary for understanding the full potential of how social media affordances can support the development of creativity. However, due to the limited use of social media in educational settings and the difficulty in collecting data using validated creativity measures, some of the studies on very specific uses of social media including small samples and using qualitative approaches to research is understandable.

One gap in the literature that was possible to identify is that several of the studies initially did not focus on creativity, but because of the exploratory nature of the studies, creativity emerged as part of the results. Another gap is that the studies focused mostly on well-established social media, and more recent or trendy platforms (e.g., Instagram and TikTok) have not been researched. These findings underscore this area as an emerging and worthwhile area of resesearch and practice.

Limitations of this study must also be considered. Although the systematic literature review methodology resulted in the identification of relevant articles, the search strategies might have excluded some other important articles. First, the search was conducted on well-established databases in education (i.e., Academic Search Premier, Education Full Text, Education Source, ERIC, and PsychINFO); however other databases could have added more potential articles to be analyzed. Second, only publications written in English were selected, which excludes works in other languages 
that could be relevant. Third, the descriptors used were carefully chosen; however the addition of other descriptors could have potentially enhanced the search.

Finally, teachers and researchers can be creative in proposing new uses for social media in educational contexts. A possibility is using social media to create personal learning environments (PLE). By creating a PLE, students can select a combination of tools to create an environment that supports creativity while meeting unique needs, interests, and goals. Also, this shifts decisionmaking autonomy to students from the teacher. Teachers can also promote creativity development, by designing instruction that requires students to create products that may be visible to audiences outside classroom boundaries. These audiences can include members of the community and content experts that can bring their unique perspectives to exchange ideas and experiences with students. Other well-known affordances (e.g., editability, searchability, persistence) have yet to be explored in relation to creativity, and new affordances can be identified and examined related to creativity. There is much to be explored about the interaction between creativity and social media in educational contexts.

\section{References}

Alias, N., Siraj, S., Azman, M.K., Daud, M., \& Hussin, Z. (2013). Effectiveness of Facebook based learning to enhance creativity among Islamic studies students by employing ISMAN instructional design model. The Turkish Online Journal of Educational Technology, 12(1), 60-67.

Altanopoulou, P., Tselios, N., Katsanos, C., Georgoutsou, M., \& Panagiotaki, M.A. (2015). Wiki-mediated activities in higher education: Evidence-based analysis of learning effectiveness across three studies. Educational Technology \& Society, 18(4), 511-522.

Amabile, T. (1996). Creativity in context. Boulder, CO: Westview Press.

Auttawutikul, S., Wiwitkunkasem, K., \& Smith, D.R. (2014). Use of weblogs to enhance group learning and design creativity amongst students at a Thai University. Innovations in Education and Teaching International, 51(4), 378-388. https://doi.org/10.1080/14703297.2013/796723

Bakla, A. (2020). Extensive reading and Web 2.0 tools in tandem: A mixed-methods study. Education and Information Technologies, 5, 3131-3160. https://doi.org/10.1007/s10639-020-10103-9

Beghetto, R.A., \& Kaufman, J.C. (2014). Classroom contexts for creativity. High Ability Studies, 25(1), 53-69. https://doi.org/10.1080/13598139.2014.905247

Bolden, B., \& Nahachewsky, J. (2015). Podcast creation: A methodology for exploring self within music teacher education. Journal of Music, Technology \& Education, 8(3), 243-260. https://doi.org/10.1386/ jmte.8.3.243_1

Boulos, M.N.K., \& Wheeler, S. (2007). The emerging Web 2.0 social software: An enabling suite of sociable technologies in health and health care education. Health Information and Libraries Journal, 24, 2-23. https://doi.org/10.1111/j.1471-1842.2007.00701.x

Bower, M. (2016). Deriving a typology of Web 2.0 learning technologies. British Journal of Educational Technology, 47(4), 763-777. https://doi.org/10.1111/bjet.12344

boyd, d.m. (2014). It's complicated: The social lives of networked teens. New Haven, CT: Yale University Press.

Bruns, A. (2008). Blogs, Wikipedia, Second Life, and beyond: From production to produsage. New York, NY: Peter Lang Publishing.

Bull, P.H., \& Adams, S. (2012). Learning technologies: Tweeting in a high school social studies class. Journal of Educational Technology, 8(4), 26-33. https://doi.org/10.26634/JET.8.4.1644 
Chang, Y.S. (2019). The mediating role of motivation for creative performance of cloud-based m-learning. Australasian Journal of Educational Technology, 35(4), 34-45. https://doi.org/10.14742/ajet.4418

Chemero, A. (2003). An outline of a theory of affordances. Ecological Psychology, 15(2), 181-195. https://doi. org/10.1207/S15326969ECO1502_5

Chen, Y.H., Jang, S.J., \& Chen, P.J. (2015). Using wikis and collaborative learning for science teachers' professional development. Journal of Computer Assisted Learning, 31, 330-344. https://doi.org/10.1111/ jcal.12095

Cochrane, T., \& Narayan, V. (2017). Design considerations for mobile learning. In C.M. Reigeluth, B.J. Beatty, \& R.D. Myers (Eds.), Instructional-design theories and models, Volume IV: The learner-centered paradigm of education (pp. 385-413). New York, NY: Routledge.

Cook, V., Major, L., Warwick, P., \& Vrikki, M. (2020). Developing collaborative creativity through microblogging: A material-dialogic approach. Thinking Skills and Creativity, 37, 1-11. https://doi.org/10.1016/ j.tsc.2020.100685

Crilly, P., \& Kayyali, R. (2020). The use of social media as a tool to educate United Kingdom undergraduate pharmacy students about public health. Currents in Pharmacy Teaching and Learning, 12, 181-188. https://doi.org/10.1016/j.cptl.2019.11.012

Daud, M.Y., \& Khalid, F. (2014). Nurturing the $21^{\text {st }}$ century skills among undergraduate students through the application and development of weblog. International Education Studies, 7(13), 123-129. https://doi. org/10.5539/ies.v7n13p123

Dennen, V.P. (2018). Social media and instructional design. In R.A. Reiser \& J.V. Dempsey (Eds.), Trends and Issues in Instructional Design and Technology (4th ed., pp. 237-243). Hoboken, NJ: Pearson Education.

Ferguson, R. (2011). Meaningful learning and creativity in virtual worlds. Thinking Skills and Creativity, 6(3), 169-178. https://doi.org/10.1016/j.tsc.2011.07.001

Frydenberg, M., \& Andone, D. (2016). Creating micro-videos to demonstrate technology learning and digital literacy. Technology Learning and Digital Literacy, 13, 261-273. https://doi.org/10.1108/ITSE-09-20160030

Gachago, D., Livingston, C., \& Ivala, E. (2016). Podcasts: A technology for all? British Journal of Educational Technology, 47(5), 859-872. https://doi.org/10.1111/bjet.12483

Galan, N., \& Khodabandehloo, A. (2016). Learning with Linkedln: Students' perceptions of incorporating subject-related blogging in an international marketing course. Interactive Technology and Smart Education, 13(2), 166-183. https://doi.org/10.1108/ITSE-10-2015-0033

Garcia-Garcia, C., Chulvi, V., \& Royoca, M. (2017). Knowledge generation for enhancing design creativity through co-creative virtual learning communities. Thinking Skills and Creativity, 24, 12-19. https://doi. org/10.1016/j.tsc.2017.02.009

Gaver, W.W. (1991). Technology Affordances. Paper presented at the Proceedings of SIGCHI Conference on Human Factors in Computing Systems, New York, NY.

Green, L.S., Inan, F.A., \& Maushak, N.J. (2014). A case study: The role of student-generated vidcasts in K-12 language learner academic language and content acquisition. Journal of Research on Technology in Education, 46(3), 297-324. https://doi.org/10.1080/15391523.2014.888295

Greeno, J. G. (1994). Gibson's affordances. Psychological Review, 101(2), 336-342. https://doi.org/10.1037/0033295X.101.2.336

Hargrove, R.A. (2013). Assessing the long-term impact of a metacognitive approach to creative skill development. International Journal of Technology and Design Education, 23, 489-517. https://doi.org/10.1007/ s10798-011-9200-6

Helwa, H.S.A.H.A. (2020). Using a program based on mobile computer - supported collaborative learning and social media applications in developing student teachers' EFL creative reading skills and cultural awareness. Journal of Education, 75, 1-48. https://doi.org/10.21608/edusohag.2020.96954

Hennessey, B.A., \& Amabile, T.M. (2010). Creativity. Annual Reviews of Psychology, 61, 569-598. https://doi. org/10.1146/annurev.psych.093008.100416 
Jang, S.J. (2009). Exploration of secondary students' creativity by integrating web-based technology into an innovative science curriculum. Computers \& Education, 52, 247-255. https://doi.org/10.1016/ j.compedu.2008.08.002

Jenkins, H., Purushotma, R., Weigel, M., Clinton, K., \& Robison, A.J. (2009). Confronting the challenges of participatory culture: Media education for the 21st Century. Boston: The MIT Press.

Kaufman, J.C., \& Beghetto, R.A. (2009). Beyond big and little: The four c model of creativity. Review of General Psychology, 13, 1-13. https://doi.org/10.1037/a0013688

Kimmons, R. (2014). Social networking sites, literacy, and the authentic identity problem. TechTrends: Linking Research \& Practice to Improve Learning, 58(2), 93-98. https://doi.org/10.1007/s11528-014-0740-y

Kivunja, C. (2015). The efficacy of social media technologies in academia: A pedagogical bliss or digital fad? International Journal of Higher Education, 4(4), 33-44. https://doi.org/10.5430/ijhe.v4n4p33

Koehler, A.A., \& Ertmer, P.A. (2016). Using Web 2.0 tools to facilitate case-based instruction: Considering the possibilities. Educational Technology, 56(1), 3-13.

Koehler, A.A., Newby, T.J., \& Ertmer, P.A. (2017). Examining the role of Web 2.0 tools in supporting problem solving during case-based instruction. Journal of Research on Technology in Education, 49(3-4), 182-197. https://doi.org/10.1080/15391523.2017.1338167

Koehler, A.A., \& Vilarinho-Pereira, D. R. (November, 2020). Using social media affordances: a conceptual framework for facilitating problem-solving skills. Paper session presented at the meeting of Association for Educational Communications \& Technology, Virtual Convention.

Lau, W.W., Lui, V., \& Chu, S.K.W. (2017). The use of wikis in a science inquiry-based project in a primary school. Educational Technology Research and Development, 65, 533-553. https://doi.org/10.1007/s11423-0169479-9

Lee, J., \& Bonk, C.J. (2016). Social network analysis of peer relationships and online interactions in a blended class using blogs. Internet and Higher Education, 28, 35-44. https://doi.org/10.1016/ j.iheduc.2015.09.001

Lee, K.S., \& Kim, B.G. (2016). Cross space: The exploration of SNS-based writing activities in a multimodal learning environment. Educational Technology \& Society, 19(2), 57-76.

Lim, J., \& Newby, T.J. (2020). Preservice teachers' Web 2.0 experiences and perceptions on Web 2.0 as a personal learning environment. Journal of Computing in Higher Education, 32, 234-260. https://doi. org/10.1007/s12528-019-09227-w

Liu, C.C., Lu, K.H., Wu, L.Y., \& Tsai, C.C. (2016). The impact of peer review on creative self-efficacy and learning performance in Web 2.0 learning activities. Educational Technology \& Society, 19(2), 286-297. https:// www.jstor.org/stable/jeductechsoci.19.2.286

Loveless, A. (2007). Literature review in creativity, new technologies and learning. Retrieved February 14, 2020, from www.futurelab.org.uk/research/lit_reviews.htm

Magnuson, M.L. (2013). Web 2.0 and information literacy instruction: aligning technology with ACRL standards. The Journal of Academic Librarianship, 39, 244-251. https://doi.org/10.1016/j.acalib.2013.01.008

Mao, J. (2014). Social media for learning: A mixed methods study on high school students' technology affordances and perspectives. Computers in Human Behavior, 33, 213-223. https://doi.org/10.1016/ j.chb.2014.01.002

McCay-Peet, L., \& Quan-Haase, A. (2016). What is social media and what questions can social media research help us answer? In L. Sloan, \& A. Quan-Haase (Eds.), The SAGE Handbook of Social Media Research Methods (pp. 13-26). London: SAGE.

Meschoulam, M., Muhech, A., Naanous, T., Quintanilla, S., Aguilar, R., Ochoa, J., \& Rodas, C. (2019). The complexity of multilateral negotiations: Problem or opportunity? A qualitative study of five simulations with Mexican students. International Studies Perspectives, 20, 265-286. https://doi.org/10.1093.isp/ ekz003

Novak, E., \& Mulvey, B.K. (2020). Enhancing design thinking in instructional technology students. Journal of Computer Assisted Learning, 37, 80-90. https://doi.org/10.1111/jcal.12470 
OECD (2015). Education at a Glance 2015: OECD Indicators. OECD Publishing. https://doi.org/10.1787/eag2015-en

Oliver, K. (2010). Integrating Web 2.0 across the curriculum. TechTrends: Linking Research \& Practice to Improve Learning, 54(2), 50-60. https://doi.org/10.1007/s11528-010-0382-7

Orehovački, T., Bubaš, G., \& Kovačić, A. (2012). Taxonomy of Web 2.0 applications with educational potential. In C. Cheal, J. Coughlin, \& S. Moore (Eds.), Transformation in teaching: Social media strategies in higher education (pp. 43-72). Santa Rosa, CA: Informing Science Press.

Paraskeva, F., Alexiou, A., Koroneou, L., Mysirlaki, S., Geomelou, A., Souki, A. M., \& Chatziiliou, A. (2015). The development of creative thinking through six thinking hats and Web 2.0 technologies. The International Journal of Technologies in Learning, 22(2), 15-28. https://doi.org/10.18848/2327-0144/CGP/ v22i02/49161

Peppler, K. (2010). Media arts: Arts education for a digital age. Teachers College Record, 112(8), 2118-2153.

Peppler, K. (2013). Social media and creativity. In D. Lemish (Ed.), The Routledge International Handbook of Children, Adolescents and Media (pp. 193-200). New York, NY: Routledge.

Rasheed, M.I., Malik, M.J., Pitafi, A.H., Iqbal, J., Anser, M.K., \& Abbas, M. (2020). Usage of social media, student engagement, and creativity: The role of knowledge sharing behavior and cyberbullying. Computers \& Education, 159, 104002. https://doi.org/10.1016/j.compedu.2020.104002

Reigeluth, C.M., \& Moore, J. (1999). Cognitive education and the cognitive domain. In C.M. Reigeluth (Ed.), Instructional-design theories and models, Volume II: A new paradigm of instructional theory (pp. 51-68). Mahwah, NJ: Lawrence Erlbaum Associates.

Rice, R.E., Evans, S.K., Pearce, K.E., Sivunen, A., Vitak, J., \& Treem. J. W. (2017). Organizational Media Affordances: Operationalization and associations with media use. Journal of Communication, 67(1), 106-130. https://doi.org/10.1111/jcom.12273

Rideout, V., Foehr, U., \& Roberts, D. (2010). Generation M2: Media in the lives of 8- to 18-year-olds. Menlo Park, CA: Kaiser Family Foudation.

Risser, H.S., Bottoms, S., \& Clark, C. (2019). "Nobody else organized": Teachers solving problems of practice in the Twitterblogosphere. Educational Media International, 56(4), 269-284. https://doi.org/10.1080/09 523987.2019.1681111

Runco, M. (2015). The real creativity crisis. Creativity \& Human Development. Retrieved from: https://creativityjournal.net/contents/articles/item/286-the-real-creativity-crisis

Runco, M.A., \& Jaeger, G. J. (2012). The standard definition of creativity. Creativity Research Journal, 24(1), 92-96. https://doi.org/10.1080/10400419.2012.650092

Sari, A.B.P., Sarana, B., Dardjito, H., \& Azizah, D.M. (2020). EFL students' improvement through the reflective YouTube video project. International Journal of Instruction, 13(4), 393-408. https://doi.org/10.29333/ iji.2020.13425a

Scott, K.S., Sorokti, K. H., \& Merrell, J. D. (2016). Learning "beyond the classroom" within an enterprise social network system. Internet and Higher Education, 29, 75-90. https://doi.org/10.1016/j.iheduc.2015.12.005

Stolaki, A., \& Economides, A.A. (2018). The creativity challenge game: An educational intervention for creativity enhancement with the integration of information and communication technologies (ICTs). Computers \& Education, 123, 195-211. https://doi.org/10.1016/j.compedu.2018.05.009

Sun, Z., Lin, C.H., Wu, M., Zhou, J., \& Luo, L. (2018). A tale of two communication tools: Discussion-forum and mobile instant-messaging apps in collaborative learning. British Journal of Educational Technology, 49(2), 248-61. https://doi.org/10.1111.bjet.12571

Surgenor, D., McMahon-Beattie, U.S.M., Burns, A., \& Hollywood, L.E. (2016). Promoting creativity in the kitchen: Digital lessons from the learning environment. The Journal of Creative Behavior, 50(3), 186-192. https://doi.org/10.1002/jocb.143

Treem, J. W., \& Leonardi, P.M. (2013). Social media use in organizations: Exploring the affordances of visibility, editability, persistence, and association. Annals of the International Communication Association, 36(1), 143-189. https://doi.org/10.1080/23808985.2013.11679130 
Valiente-Neighbours, J.M. (2020). Honoring Student Cultural Capital: Social Media and Popular Culture as Tools for Teaching Theory. College Teaching, 68(2), 79-86. https://doi.org/10.1080/87567555.2020.1741 502

Widodo, H.P., Budi, A.B., \& Wijayanti, F. (2016). Poetry writing 2.0: Learning to write creatively in a blended language learning environment. Electronic Journal of Foreign Language Teaching, 13(1), 30-48.

Wood, P. (2012). Blogs as liminal space: Student teachers at the threshold. Technology, Pedagogy and Education, 21(1), 85-99. https://doi.org/10.1080/1475939X.2012.659885

Yeo, H., \& Lee, Y. L. (2014). Exploring new potentials of blogs for learning: Can children use blogs for personal information management (PIM)? British Journal of Educational Technology, 45(5), 916-925. https://doi. org/10.1111/bjet.12117

Zhao, Y., Liu, J., Tang, J., \& Zhu, Q. (2013). Conceptualizing perceived affordances in social media interaction design. Aslib Proceedings, 65(3), 289-302. https://doi.org/10.1108/00012531311330656 